UDC 613.6: 061.5: 629.7

DOI: $10.21668 /$ health.risk/2020.1.07.eng

\title{
ASSESSING OCCUPATIONAL RISKS FOR WORKERS EMPLOYED AT HEAT-POWER ENGINEERING ENTERPRISES
}

\section{M.V. Kuleshova, V.A. Pankov}

East-Siberian Institute of Medical and Ecological Research, 12 a the 3rd micro-district, Angarsk, 665827, Russian Federation

\begin{abstract}
Our research goal was to assess occupational health risks and analyze whether it was possible to assess occupational risks for workers employed at heat-power engineering enterprises applying the same procedures as those used in the our research.

Our research involved basic occupational groups of workers employed at a heat-power engineering enterprise. They were power generating unit drivers, repairmen, and electricians responsible for electric machinery repair and maintenance. Hygienic assessment of working conditions was performed according to the valid regulatory and methodical documents. Occupational morbidity was analyzed on the basis of data arrays that contained data taken from Reports on occupational diseases (intoxications). Occupational risks were assessed as per Fine Kinney risk assessment method, matrix method, and Guide R 2.2.1766-2003; we also performed a semi-quantitative risk assessment.

Labor performed by power generating unit drivers belonged to 3.2 hazard category as per related hazards, its hardness, and intensity; repairmen, 3.3 hazard category; electricians responsible for electrical machinery repair and maintenance, 3.3 hazard category. Occupational morbidity among workers employed at enterprises dealing with energy production and distribution in Irkutsk region was analyzed over 2000-2018; the analysis revealed there was a decrease in first diagnosed occupational diseases and the most frequent nosology was sensorineural hearing loss. Occupational risk assessment performed as per different procedures indicates that obtained results are rather ambiguous. Semi-quantitative risk assessment, Finn Kinney method, and the "Finnish" model turned out to be subjective but it is still possible to apply them provided that it is done by highly qualified experts in the sphere of labor safety and occupational risks management. The most objective risk assessment procedure allows assessing probability of damage to health applying parameters that describe deviations in adverse or hazardous occupational factors from maximum permissible concentrations and levels and a cause-and effect relation with risk (Guide $G$ 2.2.1766-03).

Key words: workers employed at heat-power engineering enterprises, working conditions, occupational morbidity, sensorineural hearing loss, occupationally morbidity, occupational risk, risk assessment procedures, occupational risk factors.
\end{abstract}

Any labor process involves a worker being exposed to industrial (occupational) factors that can cause occupational accidents and work-related diseases $[1,2]$. As per data provided by the International Labor Organization, work-related diseases and occupational accidents annually result in more than 2.2 deaths [3]. More than 300 million occupational accidents and more than 150 million occupational disease cases are registered annually all over the world. At present great efforts are being taken to make working conditions safer for workers and a promising trend here is implementation of prevention activities based on occupational risks (OR) analysis and assessment.

At present in the RF different types of OR are controlled and accounted; they are risks caused by injuries with various degrees of severity including those with lethal outcomes; risks of damage to health caused by a work-related disease; risks caused by industrial accidents and emergencies at hazardous industrial objects [4-6]. Experts employed by federal institutions use a procedure that ranks economic activities as per categories of occupational risks ${ }^{1}$; the proce-

(c) Kuleshova M.V., Pankov V.A., 2020

Marina V. Kuleshova - Candidate of Biological Sciences, Senior Researcher at the Laboratory for Ecological and Hygienic Research (e-mail: lmt angarsk@mail.ru; tel.: +7 (3955) 58-69-10 (ext. 1312); ORCID: https://orcid.org/0000-0001-9253-2028).

Vladimir A. Pankov - Doctor of Medical Sciences, Head of the Laboratory for Ecological and Hygienic Research, Senior Lecturer at the Occupational Pathology and Hygiene Department (e-mail: 1mt angarsk@mail.ru; tel.: +7 (3955) 58-69-10 (ext. 1312); ORCID: https://orcid.org/0000-0002-3849-5630).

${ }^{1}$ On obligatory social insurance against industrial accidents and work-related diseases: The Federal Law issued on July 24, 1998 No. 125-FZ. Garant. Information and legal database. Available at: https://base.garant.ru/12112505/ (30.11.2019). 
dure is based on calculation of expenses caused by all the detected work-related disease cases and industrial injuries in a branch [7]. This calculated parameter is an economic one in its essence and is applied to determine volumes of insurance payments; therefore, it can't be used to communicate work-related risks of health damage to workers.

There are multiple publications on managing OR; however, in order to manage risk properly, it is necessary to assess health risks for workers.

At present there is no unified and conventional procedure for OR assessment. Given that, various schemes and procedures for $\mathrm{OR}$ assessment are applied; they all have certain advantages and drawbacks and are used depending on specific tasks to be solved and available information ${ }^{2}$. However, it is obvious, that efficient OR management, in an organization, region, or a country as a whole, requires cohort, group, and population parameters of occupational risk that will allow ranking occupations, organizations, or branches as per risk levels $[4,8]$.

As it is well known, OR assessment usually involves a five-stage procedure that includes identification of hazards that result in risks; risk assessment and risk "ranking"; working out preventive activities; implementation of protection and preventive activities; monitoring [9]. At the stage when hazards are identifies, one can use legal and normative acts, instructions, standards, reports on inspections aimed at checking adherence to labor protection requirements, statistical data on injuries, reviews of past accidents and injuries, data on occupational and qualification properties and health of workers, monitoring results, and other reliable information sources $[4,5,8-11]$. OR assessment can be performed with variable techniques and procedures, and sometimes a combination of those is applied. Basically, there are three groups of techniques and procedures:
- statistical procedures based on determining how probable specific risks are or on examining statistical data on risks;

- expert techniques based on collecting, examining, and generalizing risk assessment results;

- calculation and analytical procedures that allow assessing a risk in case there are no statistical data on it and obtaining a quantitative assessment [5].

Use of statistical procedures allows obtaining the most reliable risk assessment provided that there is thorough monitoring and reliable data. Expert techniques can be applied practically in any activity sphere; however, their universality can sometimes be extremely low, especially when a risk is analyzed in a specific situation. Calculation and analytical procedures are the most widely spread and simple in use.

When assessing risks, one can apply both direct and indirect techniques; choice on them depends on available statistical data, purposes, and qualifications and professional skills of personnel responsible for labor protection. Direct quantitative risk assessment is possible only in a case when there are accumulated data on occupational injuries and their gravity. However, in real life conditions data on health damage are frequently either insufficient or unavailable. Should there be not enough data for statistical analysis, we should use direct qualitative assessment based on analysis that takes into account scores given to working conditions by experts or assessment teams. Some direct techniques for risk assessment are Fine-Kinney method; a technique applying weighing coefficients; a matrix method when ranking parameters related to gravity and probability are given in a matrix; Monte-Carlo modeling and Bayesian technique that apply mathematical tools of probability theory. Indirect techniques for health risk assessment apply parameters that characterize deviations in existing parameters from their standard values

\footnotetext{
${ }^{2}$ GOST R 12.0.010-2009. The system of occupational safety standards (SOSS). Systems for labor protection management. Hazard determination and risk assessment. KODEKS: the electronic fund for legal and reference information. Available at: http://docs.cntd.ru/document/1200080860 (30.11.2019).
} 
and have a cause-and-effect relation with risks. Indirect techniques for risk assessment are a technique involving use of control "checklists" that contain a list of hazards or risks; interviewing; assigning risk into categories as per categories of working conditions; analyzing true causes of accidents; ELMERI method.

There aren't sufficient data in literature on how to calculate OR for workers in multiple brunches of industry and transport [12-14], including workers employed at heat powerstations $[15,16]$.

Our research goal was to assess occupational health risks and analyze whether it was probable to apply certain risk assessment techniques to assess actual risks for workers from basic occupational groups existing at a heatand-power enterprise.

Data and methods. We accomplished our research on basic occupational groups existing in heat-and-power engineering; chosen occupations included power generating unit drivers; repairmen; electricians responsible for electric machinery repair and maintenance.

Working conditions were hygienically assessed in conformity with the existing standards and procedures accepted in the RF (sanitary rules and standards; State Standards; methodical guidelines). We examined working conditions for workers employed at a heatand-power enterprise and analyzed the obtained results.

Occupational morbidity was analyzed using a database containing data from Occupational diseases (intoxications) charts drawn up over 2000-2018 in Irkutsk region ${ }^{3}$.

OR was assessed as per Fine-Kinney method [17, 18]; matrix method [19, 20]; Guide R 2.2.1766-2003 “Assessment of occupational health risks for workers",; we also performed a semi-quantitative risk assessment [20]. We also analyzed workers' health as per data obtained via periodical medical check-ups $(n=63$, average age was $39.6 \pm 1.5$; average working experience was $13.6 \pm 1.5$ years) and calculated to what extent health disorders were work-related. Our reference group was made up of people who were not exposed to hazardous occupational factors and factors related to labor process; they were comparable with the test group in terms of their age and length of working experience $(n=50)$. Authenticity of relative risk parameters was assessed with $\chi^{2}$ criterion.

Results and discussion. Occupational factors were examined at workplaces of power generating unit drivers; repairmen; electricians responsible for electric machinery repair and maintenance. Hygienic assessment of working conditions revealed that noise reached 88-100 dBA and it was 7-13 dBA higher than the hygienic standard in average- and highfrequency ranges. As workers from these occupational groups didn't have a permanent workplace, we calculated equivalent noise levels for a work shift. They amounted to $83 \mathrm{dBA}$ for power generating unit drivers; $93 \mathrm{dBA}$, for repairmen; $92 \mathrm{dBA}$, for electricians responsible for electric machinery repair and maintenance.

Equipment applied at a heat-and-power enterprise (transporters, mills, turbogenerators, and grinders) produces not only noise, but also overall vibration that is equal to $81-83 \mathrm{~dB}$.

Microclimate at workplaces (temperature, relative humidity, and air speed) conformed to hygienic standards during warm seasons. As for cold seasons, temperature deviated from hygienic standards during them and was $8.0-14.0^{\circ} \mathrm{C}$; relative humidity and air speed were within acceptable limits. Illumination mostly conformed to hygienic standards and amounted to 60-310 luxmeter-candela.

Ash and coal dust concentrations in working area air didn't exceed MPC at basic workplaces and amounted to $1.05-5.90 \mathrm{mg} / \mathrm{m}^{3}$ and $7.1-14.3 \mathrm{mg} / \mathrm{m}^{3}$ accordingly.

\footnotetext{
${ }^{3}$ On improving the system for investigating and accounting occupational diseases in the Russian Federation (with alterations and supplements): The Order by the RF Public Healthcare ministry dated May 28, 2001 No. 176. Appendix 5. An occupational disease (intoxication) chart. Garant. Information and legal database. Available at: http://base.garant.ru/4177627/c9c989f1e999992b41b30686f0032f7d/ (30.11.2019).

${ }^{4} \mathrm{P}$ 2.2.1766-03. Occupational hygiene. Guide on assessing occupational health risks for workers. Organization and methodical basics, assessment principles and criteria: Guide. Moscow, 2003, 18 p.
} 
Hardness of labor process for workers with the examined occupations was determined by dynamic physical loads with predominantly used hand, arm and shoulder muscles when a weight was moved from a place to place over 1 meter (up to $7,000 \mathrm{~kg}^{*}$ min); static loads when a weight was held with two arms (more than 70,000 $\mathrm{kg}^{*} \mathrm{sec}$ ); uncomfortable and/or fixed body pose (up to $50 \%$ of a work shift); body bends (more than 100 per a shift); moving around due to necessities related to a technological process (up to $8 \mathrm{~km}$ horizontally and up to $2.5 \mathrm{~km}$ vertically); all these factors ranked working conditions into 3.1 and 3.2 hazard category (hard physical labor). Labor intensity (intellectual, sensory, and emotional loads; monotony and working regime) were acceptable (average labor intensity).

According to parameters characterizing hazards, labor hardness, and labor intensity, working conditions correspond to 3.2 hazard category for power generating unit drivers; 3.3 hazard category, for repairmen; 3.3 hazard category, for electricians responsible for electric machinery repair and maintenance; higher hazard category is due to workers being exposed to high noise levels.

Apart from occupational factors, working environment, and workplace ergonomics, risk factors can also occur due to moving machinery and mechanisms, moving parts of industrial equipment, surfaces of equipment and tools, and a workplace being located high above the ground or workshop floor.
We analyzed occupational morbidity in Irkutsk region in "Energy production, transfer, and distribution" over 2000-2018 and revealed that there was a decrease in detected occupational disease cases; over recent years they amounted to $1.7-6.9$ cases per 10,000 workers employed in the branch. We also analyzed the structure of occupational morbidity and revealed that sensorineural hearing loss was a basic nosology detected in workers with the examined occupations $(\mathrm{RR}=18.92, \mathrm{EF}=95 \%$, $\chi^{2}=16.71$ for repairmen; $\mathrm{RR}=13.16, \mathrm{EF}=92 \%$, $\chi^{2}=7.42$ for electricians; $\mathrm{RR}=28.57, \mathrm{EF}=97 \%$, $\chi^{2}=16.95$ for power generating unit drivers).

We calculated OR as per Fine-Kinney method based on analyzing three factors: an extent to which a worker was exposed to impacts exerted by adverse factor at a workplace $(\mathrm{P})$, a probability of a threat to health occurring at a workplace (V), and consequences for a worker's health and/or safety in case such a threat comes to life (C) $[14,17]$. The calculation revealed that OR for the examined workers was rather serious (substantial) $(\mathrm{R}=108)$ and it required planning and accomplishing activities aimed at reducing this risk (Table 1).

Semi-quantitative risk assessment calculated as per the formula $\mathrm{R}+\mathrm{Q} \times \mathrm{p}$ where $\mathrm{Q}$ is a probability of a damaging event and $p$ is consequences, severity, or a volume of losses [20] revealed that OR was acceptable for all three examined occupational groups $(\mathrm{R}<40$ scores) (Table 2).

Table 1

Occupational risk assessment as per Fine-Kinney method

\begin{tabular}{|l|c|c|c|c|c|}
\hline \multirow{2}{*}{ Occupation } & \multicolumn{3}{|c|}{ A stage in assessment } & Comments \\
\cline { 2 - 5 } & $\begin{array}{c}\text { A worker being } \\
\text { exposed to adverse } \\
\text { factors (P) }\end{array}$ & $\begin{array}{c}\text { Probability of } \\
\text { a threat at } \\
\text { workplace (V) }\end{array}$ & $\begin{array}{c}\text { Consequences } \\
\text { for a worker's } \\
\text { health (C) }\end{array}$ & Risk (R) & Coment \\
\hline $\begin{array}{l}\text { Power generating unit } \\
\text { drivers }\end{array}$ & $\frac{\text { Regular }}{6 \text { scores }}$ & $\frac{\text { Very probable }}{6 \text { scores }}$ & $\frac{\text { Injury (TD) }}{3 \text { scores }}$ & 108 & $\begin{array}{c}\text { Substantial } \\
\text { risk }\end{array}$ \\
\hline Repairmen & $\underline{\text { Regular }}$ & $\frac{\text { Very probable }}{6 \text { scores }}$ & $\frac{\text { Injury (TD) }}{3 \text { scores }}$ & 108 & $\begin{array}{c}\text { Substantial } \\
\text { risk }\end{array}$ \\
\hline $\begin{array}{l}\text { Electricians responsible } \\
\text { for electric machinery } \\
\text { repair and maintenance }\end{array}$ & $\underline{\text { Regular }}$ & $\frac{\text { Very probable }}{6 \text { scores }}$ & $\frac{\text { Injury (TD) }}{3 \text { scores }}$ & 108 & $\begin{array}{c}\text { Substantial } \\
\text { risk }\end{array}$ \\
\hline
\end{tabular}

Note: TD means temporary disability. 
Table 2

Semi-quantitative occupational risk assessment

\begin{tabular}{|l|c|c|c|c|}
\hline \multicolumn{1}{|c|}{ Occupation } & Probability, Q & Severity, $\mathrm{p}$ & $\begin{array}{c}\text { Risk (R), } \\
\text { score }\end{array}$ & $\begin{array}{c}\text { Risk } \\
\text { level }\end{array}$ \\
\hline $\begin{array}{l}\text { Power generating unit } \\
\text { drivers }\end{array}$ & $\frac{\text { Very probable }}{8 \text { scores }}$ & $\begin{array}{c}\text { Temporary disability } \\
\text { for less than 4 weeks }\end{array}$ & 32 & Acceptable \\
\hline Repairmen & $\frac{\text { Very probable }}{8 \text { scores }}$ & $\begin{array}{l}\text { Temporary disability } \\
\text { for less than 4 weeks }\end{array}$ & 32 & Acceptable \\
\hline $\begin{array}{l}\text { Electricians responsible } \\
\text { for electric machinery } \\
\text { repair and maintenance }\end{array}$ & $\frac{\text { Very probable }}{8 \text { scores }}$ & $\begin{array}{l}\text { Temporary disability } \\
\text { for less than 4 weeks }\end{array}$ & 32 & Acceptable \\
\hline
\end{tabular}

We also applied a so called "Finnish" risk management model to analyzed OR [19]; the analysis revealed that risk index corresponded to unacceptable risk for all the examined occupations (Table 3 ).

We assessed a priori risk as per data obtained via special assessment of working conditions and sanitary-industrial control as well as occupational morbidity index (according to G 2.2.1766-03); the assessment revealed that OR taken as per working conditions were average (substantial) for power generating units drivers; and high (intolerable) for repairmen and electricians responsible for electric machinery repair and maintenance (Table 4).

We calculated occupational morbidity index and revealed that risks were extremely high for all three examined occupational groups (Table 5).

Table 3

Occupational risk assessment as per "Finnish" model

\begin{tabular}{|l|c|c|c|c|}
\hline \multicolumn{1}{|c|}{ Occupation } & $\begin{array}{c}\text { Frequency } \\
\text { of accidents }\end{array}$ & $\begin{array}{c}\text { Hazard } \\
\text { category }\end{array}$ & $\begin{array}{c}\text { Risk } \\
\text { index }\end{array}$ & $\begin{array}{c}\text { Risk } \\
\text { criterion }\end{array}$ \\
\hline $\begin{array}{l}\text { Power generating unit } \\
\text { drivers }\end{array}$ & $\frac{\text { Probable }}{\mathrm{B}}$ & $\frac{\text { Substantial }}{2}$ & $2 \mathrm{~B}$ & Unacceptable \\
\hline Repairmen & $\frac{\text { Probable }}{\mathrm{B}}$ & $\frac{\text { Substantial }}{2}$ & $2 \mathrm{~B}$ & Unacceptable \\
\hline $\begin{array}{l}\text { Electricians responsible } \\
\text { for electric machinery } \\
\text { repair and maintenance }\end{array}$ & $\frac{\text { Probable }}{\mathrm{B}}$ & $\frac{\text { Substantial }}{2}$ & 2B & Unacceptable \\
\hline
\end{tabular}

Table 4

Working conditions and occupational risk categories

\begin{tabular}{|l|c|c|c|}
\hline \multicolumn{1}{|c|}{ Occupation } & $\begin{array}{c}\text { Working conditions cate- } \\
\text { gory as per G 2.2.2006- } \\
05\end{array}$ & $\begin{array}{c}\text { Occupational } \\
\text { risk category }\end{array}$ & $\begin{array}{c}\text { Urgency of activities } \\
\text { aimed at reducing risks }\end{array}$ \\
\hline $\begin{array}{l}\text { Power generating unit } \\
\text { drivers }\end{array}$ & $\begin{array}{l}3.2 \text { (hazardous, } \\
\text { the } 2^{\text {nd }} \text { degree) }\end{array}$ & $\begin{array}{c}\text { Average (substantial) } \\
\text { risk }\end{array}$ & $\begin{array}{c}\text { Activities aimed at re- } \\
\text { ducing risks are required }\end{array}$ \\
\hline Repairmen & $\begin{array}{l}3.3 \text { (hazardous, } \\
\text { the } 3^{\text {rd }} \text { degree) }\end{array}$ & $\begin{array}{c}\text { High (intolerable) } \\
\text { risk }\end{array}$ & $\begin{array}{c}\text { Urgent activities aimed } \\
\text { at reducing risks are } \\
\text { required }\end{array}$ \\
\hline $\begin{array}{l}\text { Electricians responsible } \\
\text { for electric machinery } \\
\text { repair and maintenance }\end{array}$ & $\begin{array}{l}3.3 \text { (hazardous, } \\
\text { the } 3^{\text {rd }} \text { degree) }\end{array}$ & $\begin{array}{c}\text { High (intolerable) } \\
\text { risk }\end{array}$ & $\begin{array}{c}\text { Urgent activities aimed } \\
\text { at reducing risks are } \\
\text { required }\end{array}$ \\
\hline
\end{tabular}


Table 5

Occupational morbidity index and occupational risk categories

\begin{tabular}{|l|c|c|c|}
\hline \multicolumn{1}{|c|}{ Occupation } & $\begin{array}{c}\text { Occupational } \\
\text { morbidity index }\end{array}$ & $\begin{array}{c}\text { Occupational } \\
\text { risk category }\end{array}$ & $\begin{array}{c}\text { Urgency of activities aimed } \\
\text { at reducing risks }\end{array}$ \\
\hline $\begin{array}{l}\text { Power generating unit } \\
\text { drivers }\end{array}$ & 0.5 & $\begin{array}{c}\text { Extremely high } \\
\text { (intolerable) risk }\end{array}$ & $\begin{array}{c}\text { It is forbidden to start or continue } \\
\text { any work before risks are reduced }\end{array}$ \\
\hline Repairmen & 0.5 & $\begin{array}{c}\text { Extremely high } \\
\text { (intolerable) risk }\end{array}$ & $\begin{array}{l}\text { It is forbidden to start or continue } \\
\text { any work before risks are reduced }\end{array}$ \\
\hline $\begin{array}{l}\text { Electricians responsible } \\
\text { for electric machinery } \\
\text { repair and maintenance }\end{array}$ & 0.5 & $\begin{array}{c}\text { Extremely high } \\
\text { (intolerable) risk }\end{array}$ & $\begin{array}{l}\text { It is forbidden to start or continue } \\
\text { any work before risks are reduced }\end{array}$ \\
\hline
\end{tabular}

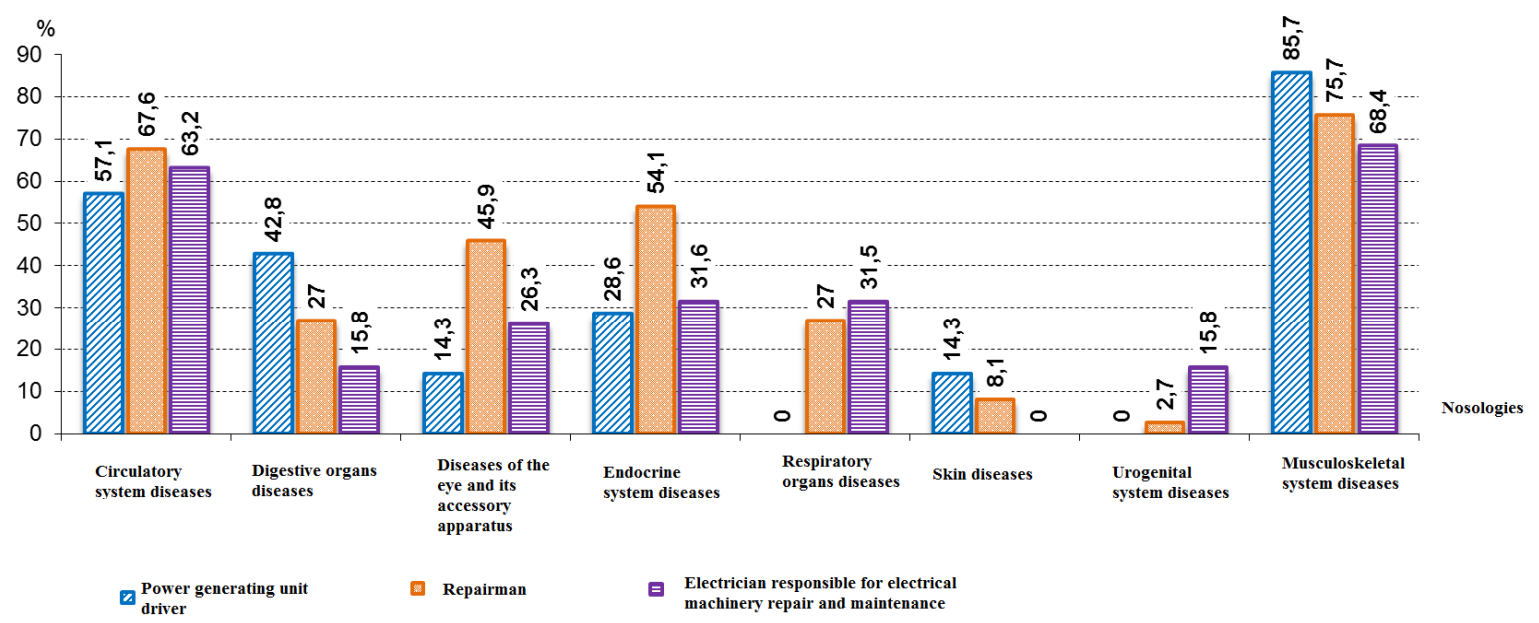

Figure 1. Frequency of chronic common diseases revealed in workers due to periodical medical examinations (per 100 workers)

In addition to a priori assessment of occupational risks as per working conditions, we analyzed frequency of common chronic diseases revealed in workers due to periodical medical examinations and assessed to what extent they were work-related (as per Guide 2.2.1766-03).

We established that power generating unit drivers, repairmen, and electricians responsible for electrical machinery repair and maintenance most frequently suffered from diseases of the musculoskeletal system and connective tissue; most common diseases were low-back pains, neck pains, and pains in the thoracic spine ( 75.7 cases, 68.4 cases, and 85.7 cases per 100 examined workers accordingly) (Figure 1).

We revealed almost complete occupational causality of these nosologies among workers with the examined occupations $\left(\mathrm{RR}=7.57, \mathrm{EF}=87 \%, \chi^{2}=36.22 ; \mathrm{RR}=6.84\right.$,
$\mathrm{EF}=85 \%, \chi^{2}=21.44 ; \mathrm{RR}=8.57, \mathrm{EF}=88 \%$, $\chi^{2}=18.00$ accordingly). Besides, we established practically complete occupational causality of diseases of the eye and adnexa its accessory apparatus for repairmen and electricians $\left(\mathrm{RR}=22.97, \mathrm{EF}=96 \%, \chi^{2}=22.42 ; \mathrm{RR}=13.16\right.$, $\mathrm{EF}=92 \%, \chi^{2}=7.42$ accordingly). We should note that there was also almost complete occupational causality for all three occupational groups regarding health disorders in the endocrine system, namely, obesity, diabetes mellitus, and diffuse thyroid gland enlargement $\left(\mathrm{RR}=27.03, \mathrm{EF}=96 \%, \chi^{2}=28.69\right.$ for repairmen; $\mathrm{RR}=14.29, \mathrm{EF}=93 \%, \chi^{2}=4.18$ for power generating unit drivers; $\mathrm{RR}=15.79$, $\mathrm{EF}=94 \%, \chi^{2}=10.17$ for electricians). Circulatory system diseases were also rather widely spread among workers from the examined occupational groups as per data obtained via periodical medical examinations; despite that, 
comparative analysis didn't reveal any statistically significant discrepancies from the reference group as per these nosologies.

Conclusion. Therefore, our research revealed that applying different procedures for assessing OR for workers employed at a heatand-power enterprise yielded somewhat contradictory results. OR assessment as per FineKinney method and "Finnish" model doesn't involve either instrumental or laboratory measurements or clinical, physiological, medical-biological, and epidemiologic research; however, it does allow determining whether there is a risk to get injured. Besides, semi-quantitative OR assessment, FineKinney method, and "Finnish" model have a serious drawback as they employ rather subjective approach to occupational risk assessment; at the same time, they should be given some attention, especially provided that there are skilled experts in labor protection and OR management who have relevant knowledge in specific industrial brunches. In our opinion, the most objective procedure for assessing occupational health risks is a procedure that allows assessing probability of damage to health and employs such parameters that characterize deviation of occupational and industrial factors (concentrations, doses, levels, etc.) from hygienic standards and have a cause-and-effect relation with risks. When OR are calculated as per this procedures, experts take into account factor values, duration of exposure to them, and workers' health; however, should there be no long-term occupational morbidity in an organization, it becomes rather difficult to qualitatively assess OR. Besides, OR assessment as per Guide 2.2.1766-03 doesn't allow assessing risks of injuries but at the same time it is quite possible to assess to what extent diseases are workrelated or occupational and it provides much better insight into OR essence.

Funding. The research was accomplished due to funding provided for finding solutions to tasks fixed by state authorities for the East Siberian Institute for Medical and Ecological Research

Conflict of interests. The authors declare there is no any conflict of interests.

\section{References}

1. Levashov S.P., Shkrabak V.S. Professional'nyi risk: metodologiya monitoring i analiza [Occupational risk: monitoring and analysis methodology]. Kurgan, Izdatel'stvo Kurganskogo gosudarstvennogo universiteta Publ., 2015, 308 p. (in Russian).

2. Kokangül A., Polat U., Dag suyu C. A new approximation for risk assessment using the AHP and Fine Kinney methodologies. Safety Science, 2017, no. 91, pp. 24-32. DOI: 10.1016/j.ssci.2016.07.015

3. Sait Mezhdunarodnoi organizatsii truda [The World Health Organization official web-site]. Available at: https:/www.ilo.org/moscow/areas-of-work/occupational-safety-and-health/WCMS_249276/lang-$\mathrm{ru} /$ index.htm (30.11.2019) (in Russian).

4. Malyshev D.V. Metod kompleksnoi otsenki professional'nogo riska [A complex procedure for occupational risk assessment]. Problemy analiza riska, 2008, vol. 5, no. 3, pp. 40-59 (in Russian).

5. Professional'nyi risk. Teoriya i praktika rascheta [Occupational risk. Theoretical and practical aspects of calculating it]. In: A.G. Khrupachev, A.A. Khadartsev eds. Tula, Izdatel'stvo Tul'skogo gosudarstvennogo universiteta Publ., 2011, 330 p. (in Russian).

6. Khrupachev A.G., Khadartsev A.A., Kamenev L.I., Panova I.V., Sedova O.A. Metodologicheskaya kontseptsiya professional'nogo riska i ego kolichestvennaya otsenka [A methodological concept for occupational risk and its quantitative assessment]. Natsional'nye interesy: prioritety i bezopasnost', 2010, vol. 92, no. 35, pp. 69-80 (in Russian).

7. Simonova N.I., Denisov E.I. Otechestvennye i mezhdunarodnye podkhody k otsenke i upravleniyu professional'nymi riskami. Zakonodatel'stvo Rossiiskoi Federatsii i normativno-pravovye akty, kasayushchiesya professional'nogo riska [Domestic and international approaches to assessing and managing occupational risks. The RF legislation and legal and regulatory documents related to occupational risks]. Aktual'nye problemy «Meditsiny truda»: sbornik trudov NII meditsiny truda. In: N.F. Izmerov ed. Moscow, Reinfor Publ., 2010, 416 p. (in Russian). 
8. Levashov S.V. Otsenka professional'nykh riskov v RF i za rubezhom [Occupational risk assessment in the RF and abroad]. Problemy analiza riska, 2012, vol. 9, no. 6, pp. 54-66 (in Russian).

9. Risk Assessment Tool. Available at: https://osha.europa.eu/en/publications/risk-assessment-tool (30.11.2019)

10. Bukhtiyarov I.V., Bobrov A.F., Denisov E.I., Eremin A.L., Kur'erov N.N., Losik T.K., Pochtareva E.S., Prokopenko L.V. [et al.]. Occupational risk assessment methods and their information support. Gigiena i sanitariya, 2019, vol. 98, no. 12, pp. 1327-1330. DOI: 10.18821/0016-9900-2019-98-12-1327-1330

11. Bulavka Yu.A. Current state and development of methodology of expert assessment of occupational workplace risk. Vestnik Polotskogo gosudarstvennogo universiteta. Seriya B, 2013, no. 3, pp. 156-163 (in Russian).

12. Kowalczyk A., Chodoła I., Kulczycka K., Stychno E. Characteristics of selected methods of risk assessment. Journal of Education, Health and Sport, 2018, vol. 8, no. 9, pp. 1703-1714. DOI: 10.5281/zenodo. 1438817

13. Khairullina L.I., Tuchkova O.A., Zinnatullina G.N. Assessment of professional risks in industrial enterprises: examples of registration of professional risk cards. Nauchnye Trudy KubGTU, 2019, no. 3, pp. 504-511 (in Russian).

14. Bednarzhevskii S.S., Korol' Zh.V. Application of Fine-Kinney Method for Occupational Risk Assessment. Perspektivy nauki, 2013, vol. 43, no. 4, no. 74-77 (in Russian).

15. Denisov E.I. Noise at a workplace: permissible noise levels, risk assessment and hearing loss prediction. Health Risk Analysis, 2018, no. 3, pp. 13-23. DOI: 10.21668/health.risk/2018.3.02.eng

16. Kochakova A.A., Ivanova M.V. Otsenka professional'nogo riska rabotnikov predpriyatii TEK [Occupational risk assessment for workers employed at heat-power engineering enterprises]. Nauka $i$ obrazovanie segodnya, 2019, vol. 41, no. 6-1, pp. 32-34 (in Russian).

17. Oturakçi M., Dağsuyu C., Kokangül A. A New Approachto Fine Kinney Method and an Implementation Study. Alphanumeric Journal, 2015, vol. 3, no. 2, pp. 083-092. DOI: 10.17093/aj.2015.3.2.5000139953

18. Latypova R.R., Khait D.D., Kandybko A.P. Foreign experience of assessment of risks. Aktual'nye problemy ekonomiki i upravleniya, 2018, vol. 19, no. 3, pp. 75-77 (in Russian).

19. Murtonen M. Otsenka riskov na rabochem meste - prakticheskoe posobie [Assessing risks existing at a workplace: a practical guide]. Tampere, Subregional'noe byuro MOT dlya stran Vostochnoi Evropy i Tsentral'noi Azii, Publ, 2007, 65 p. (in Russian).

20. Nimetulaeva G.Sh. Evaluation methods for occupational and environmental risks in occupational safety and health. Gornyi informatsionno-analiticheskii byulleten', 2016, no. 5, pp. 75-93 (in Russian).

Kuleshova M.V., Pankov V.A. Assessing occupational risks for workers employed at heat-power engineering enterprises. Health Risk Analysis, 2020, no. 1, pp. 68-75. DOI: 10.21668/health.risk/2020.1.07.eng

Received: 04.12.2019

Accepted: 09.02 .2020

Published: 30.03 .2020 